\title{
HUBUNGAN PEMBERIAN ASI DAN MP ASI DENGAN KEJADIAN STUNTING PADA BADUTA (BALITA BAWAH 2 TAHUN) DIWILAYAH KERJA PUSKESMAS KAMPUNG DALAM
}

\author{
Sri Hasanah ${ }^{1}$, Masmuri² ${ }^{2}$, Aryanto Purnomo ${ }^{3}$ \\ 1.2 STIKes Yarsi Pontianak, 3. Poltekes Kemenkes Pontianak \\ Sri Hasanah: Program Studi Pendidikan Profesi Ners, STIKes Yarsi Pontianak, \\ Jln. Panglima A`im, No.1 Pontianak Timur, Kota Pontianak, Kalimantan Barat - 78232 \\ E-mail: $\underline{\text { Srihasanah72@yahoo.com }}$
}

\begin{abstract}
ABSTRAK
Latar Belakang: Balita pendek masih menjadi masalah generasi diindonesia. Terjadinya stunting pada baduta sering kali tidak disadari, dan setelah dua tahun baru terlihat ternyata balita tersebut pendek. Tujuan Penelitian: Penelitian ini bertujuan untuk mengetahui hubungan pemberian ASI dan makanan pendamping ASI terhadap kejadian balita pendek pada baduta (balita bawah 2 tahun) diwilayah kerja Puskesmas Kampung Dalam. Jenis penelitian: Penelitian kuantitatif menggunakan rancangan penelitian observasional analitik korelatif dengan desain penelitian case control. Besar sampel yaitu 44 orang yang diambil dengan teknik purposive sampling. Analisa data menggunakan uji chi square, dengan nilai $\mathrm{P}<0,05$. Hasil penelitian: Ada hubungan pemberian ASI dengan kejadian stunting ( $\mathrm{p}$ value $=0,000$ ) dan pemberian makanan pendamping ASI dengan kejadian stunting (p value $=0,002$ ). Kesimpulan: Terdapat Hubungan yang signifikan antara ASI dan makanan pendamping ASI dengan kejadian stunting diwilayah kerja Puskesmas Kampung Dalam.
\end{abstract}

Kata Kunci: ASI, makanan pendamping ASI, pendek

\section{ABSTRACT}

Background: Stunted children is still a major generational problem in indonesia. Stunting in baduta (toddlers under 2 years) was not directly realized and can be loocked after they are 2 years old. The purpose: This study aims to find out the association betwen breastfeeding and complementary feeding in stunted baduta (toddlers under 2 years) in the working area of the Kampung Dalam community health center. Type of research: Quantitative research using a correlative analytic observational research design with case control research design. The sample size is 44 people taken by purposive sampling technique. Data analysis using chi square test, with a value of $p<0,05$. Research results: The association between breastfeeding with stunting ( $p$ value $=0,000)$ and complementary feeding with stunting $(p$ value =0,002). Conclusion: There is a significant correlation between breastfeeding and complementary feeding with stunting in the working area of the Kampung Dalam community health center.

KataKunci: breastfeeding, complementary feeding, stunted.

\section{PENDAHULUAN}

Status gizi anak balita merupakan salah satu indikator keberhasilan kesehatan yang menjadi target Millenium Development Goals (MDGs). Namun indikator ini belum berwujud karena saat ini indonesia masih menggadapi permasalahan gizi yang berdampak cukup sering terhadap kualitas sumber daya manusia. Salah satu masalah gizi yang cukup tinggi diIndonesia adalah masalah pendek (stunting) dan kurus (wasting) (warta kesmas 2018).
Stunting (kerdil) adalah kondisi dimana balita memiliki panjang atau tinggi badan yang kurang jika dibandingkan dengan umur. Kondisi ini diukur dengan panjang atau tinggi badan yang lebih dari minus dua standar deviasi median standar pertumbuhan anak dari World Healt Organisasion (WHO). Balita stunting termasuk masalah gizi kronik yang disebabkan oleh banyak faktor seperti kondisi sosial ekonomi, gizi ibu saat hamil, kesakitan pada bayi, dan kurangnya asupan gizi pada bayi. Balita stunting di masa yang 
akan datang akan mengalami kesulitan dalam mencapai perkembangan fisik dan kognitif yang optimal (Pusdatin, 2018).

Stunting dapat berakibat pada gangguan perkembangan kognitif, ketidakmampuan menerima pelajaran di sekolah, rendahnya produktifitas ekonomi saat dewasa, dan gangguan kehamilan (dewey \& begum, 2011). Selain hal tersebut stunting juga meningkatkan resiko anak terkena penyakit tidak menular saat dewasa. Hal tersebut beresiko untuk menjadi penghambat kemajuan indonesia akibat rendahnya kualitas sumber daya manusia. Stunting sebagai manifestasi masalah gizi diIndonesia, membutuhkan penyelesaian yang bersifat preventif maupun kuratif. Stunting merupakan masalah yang multikausal, perlu adanya perbaikan yang bersifat komprehensif.

Data prevalensi balita stunting yang dikumpulkan World Health Organization (WHO), Indonesia termasuk ke dalam negara ketiga dengan prevalensi tertinggi di regional Asia Tenggara/South-East Asia Regional (SEAR). Rata-rata prevalensi balita stunting di Indonesia tahun 2005-2017 adalah 36,4\%. (WHO,2017). Kejadian balita pendek atau biasa disebut dengan stunting merupakan salah satu masalah gizi yang dialami oleh balita di dunia saat ini. Pada tahun 2017 $22,2 \%$ atau sekitar 150,8 juta balita di dunia mengalami stunting. Namun angka ini sudah mengalami penurunan jika dibandingkan dengan angka stunting pada tahun 2000 yaitu $32,6 \%$.

Berdasarkan data riset kesehatan dasar (Riskesdas) prevalensi balita sangat pendek dan pendek usia 0-59 bulan di Indonesia tahun 2017 adalah 9,8\% dan 19,8\%. Kondisi ini meningkat dari tahun sebelumnya yaitu prevalensi balita sangat pendek sebesar 8,5\% dan balita pendek sebesar 19\%. Provinsi dengan prevalensi tertinggi balita sangat pendek dan pendek pada usia 0-59 bulan tahun 2017 adalah nusa tenggara timur, sedangkan provinsi dengan prevalensi terendah adalah Bali (Pusdatin, 2018).

Berdasarkan hasil PSG (pemantauan status gizi) Dinas Provinsi Kalimantan Barat di tahun 2018 prevalensi kejadian stunting sebesar 42\% (Riskesdas, 2018). Data kejadian stunting 2015, kabupaten sanggau memiliki prevalensi tinggi sebesar 40,6\%, jika dibandingkan dengan prevalensi stunting di kota pontianak sebesar $31 \%$ dan kabupaten sintang 34,8\% (Profil kesehatan provinsi 2015).

Berdasarkan angka stunting yang dikumpulkan oleh Dinas Kesahatan Kota Pontianak berdasarkan kelurahan yang paling tinggi adalah Kelurahan Tanjung Hilir yaitu sebanyak $42,0 \%$ dan yang paling rendah berada di Kelurahan Darat Sekip dan Akcaya dengan presentase balita yang mengalami stunting sebanyak 10,0\% (Dinkes, 2018).

Pemerintah melalui kementrian kesehatan berupaya menyusun program untuk mengatasi masalah stunting ini, upaya ini menjadi salah satu prioritas pembangunan nasional yang tercantum didalam sasaran pokok Rencana Pembangunan Jangka Menengah (RPJM) tahun 2015-2019. Target program ini adalah penurunan prevalensi stunting (pendek dan sangat pendek) pada anak baduta (bawah dua tahun) (info datin, 2016).

Meskipun program ini gencar didiskusikan namun masalah stunting masih tetap tinggi hal ini dikarenakan adanya beberapa faktor yang mempengaruhi kejadian stunting salah satu faktor yang dapat mempengaruhi adalah faktor asupan antara lain Air Susu Ibu (ASI) dan Makanan Pendamping ASI. Pemberian ASI secara eksklusif selama 6 bulan dan MP ASI yang tepat merupakan upaya yang mampu menurunkan angka stunting dan 
meningkatkan kelangsungan hidup anak, sedangkan ASI eksklusif yang diberikan terlalu lama akan menunda pemberian MP ASI akibatnya anak akan menerima asupan gizi yang tidak adekuat untuk menunjang proses pertumbuhan dan perkembangan (Nurkomala, 2017).

Nutrisi yang diperoleh sejak bayi lahir tentunya sangat berpengaruh terhadap pertumbuhannya termasuk risiko terjadinya stunting. Tidak terlaksananya inisiasi menyusu dini (IMD), gagalnya pemberian air susu ibu (ASI) eksklusif, dan proses penyapihan dini dapat menjadi salah satu faktor terjadinya stunting. Sedangkan dari sisi pemberian makanan pendamping ASI (MP ASI) hal yang perlu diperhatikan adalah kuantitas, kualitas, dan keamanan pangan yang diberikan (Info datin, 2016).

Berdasarkan hasil penelitian Dwitama tahun 2018 disimpulkan bahwa terdapat hubungan antara pemberian ASI eksklusif dan balita pendek tetapi tidak terdapat hubungan antara makanan pendamping ASI (MP-ASI) dan balita pendek di Kecamatan Jatinangor. Berbeda halnya dengan penelitian yang dilakukan Puji DKK pada tahun 2016 penelitian tersebut membuktikan bahwa riwayat waktu memulai pemberian MP ASI berhubungan secara signifikan dengan kejadian stunting. Dan menurut hasil penelitian Sri indrawati pada tahun 2016 bahwa terdapat hubungan antara pemberian ASI eksklusif dengan tingkat kejadian stunting pada balita usia 2-3 dan stunting dapat dicegah dengan beberapa hal seperti pemberian AS dan MP ASI yang sesuai dengan kebutuhan anak.

Dari hasil study pendahuluan yang dilakukan peneliti di posyandu wilayah kerja Puskesmas Kampung Dalam 7 dari 10 ibu mengatakan bahwa anak balitanya tidak mendapatkan ASI eksklusi bahkan ada yang tidak mendapatkan ASI sama sekali dan hanya diberikan susu formula, dan ada yang diberikan MP ASI sebelum usia 6 bulan. Dari angka prevalensi kejadian stunting yang terus meningkat dan hasil penelitian terdahulu tentang stunting maka peneliti tertarik untuk mengetahui apakah terdapat "Hubungan pemberian ASI dan MP ASI dengan kejadian stunting pada balita.

\section{METODE}

Penelitian ini menggunakan jenis penelitian kuantitatif dengan rancangan observasional analitik korelatif. Penelitian ini menggunakan desain penelitian case control yang dilaksanakan di wilayah kerja Puskesmas Kampung Dalam Pontianak Timur selama 1 bulan mulai dari pengumpulan data sampai analisis data. Populasi pada penelitian ini yaitu sebanyak 44 orang terhitung dari bulan Januari - Maret 2019. Pengambilan sampel menggunakan teknik Non Probability Sampling, jenis yang dipilih yaitu purposive sampling didapatkan sebanyak 22 orang kelompok intervensi dan 22 orang kelompok kontrol instrument penelitian menggunakan kuesioner sebanyak 2 item pertanyaan dan pernyataan tidak di uji validitas dan reabilitas karena kuisioner hanya sebagai probing. Sasaran responden yaitu penderita stunting dan bukan penderita stunting yang melakukan kunjungan ke Puskesmas Kampung Dalam. Peneliti terlebih dahulu meminta persetujuan responden melalui inform consent yang telah di tandatangani kemudian kuesioner dibagikan untuk diisi oleh responden, setelah itu diinput menggunakan program komputer dan diolah menggunakan software analisa statistik. Analisa data menggunakan uji $C h i$ square.

\section{HASIL}
A. Hasil Analisa Univariat dan Pembahsan 
Tabel 1

Distribusi Frekuensi Responden Berdasarkan Usia, Jenis Kelamin, Pendidikan Terakhir, Pekerjaan di Wilayah Kerja Puskesmas Kampung Dalam

$$
(\mathrm{N}=44)
$$

\begin{tabular}{|c|c|c|c|c|}
\hline \multirow{2}{*}{ Karakteristik } & \multicolumn{2}{|c|}{ Kasus } & \multicolumn{2}{|c|}{ Kontrol } \\
\hline & $\mathrm{n}$ & $\%$ & $\mathrm{~N}$ & $\%$ \\
\hline \multicolumn{5}{|l|}{ Jeniskelamin } \\
\hline Laki-laki & 12 & 54,5 & 11 & 50,0 \\
\hline Perempuan & 10 & 45,5 & 11 & 50,0 \\
\hline Total & 22 & 100.0 & 22 & 100.0 \\
\hline $\begin{array}{l}\text { Pendidikan } \\
\text { terakhir } \\
\text { SD }\end{array}$ & 8 & 36,4 & 3 & 13,6 \\
\hline SMP & 11 & 50,0 & 6 & 27,3 \\
\hline SMA & 3 & 13,6 & 9 & 40,9 \\
\hline PerguruanTinggi & 0 & 00,0 & 4 & 18,2 \\
\hline Total & 22 & 100.0 & 22 & 100.0 \\
\hline \multicolumn{5}{|l|}{ Pekerjaan } \\
\hline IbuRumahTangga & 12 & 54,5 & 16 & 72,7 \\
\hline PNS & 0 & 00,0 & 2 & 9,1 \\
\hline Swasta/Pedagang & 10 & 45,5 & 4 & 18,2 \\
\hline Total & 22 & 100.0 & 22 & 100.0 \\
\hline
\end{tabular}

Sumber : data primer2019

Hasil penelitian menunjukan jenis kelamin responden lebih banyak laki-laki sebanyak 23 responden $(53,3 \%)$ diantaranya 12 responden berada pada kelompok kasus.Jenis kelamin salah satu faktor yang mempengaruhi kejadian stunting pada balita. Perempuan lebih banyak mengandung lemak dalam tubuhnya yang berarti bahwa lebih banyak jaringan tidak aktif dalam tubuhnya meskipun berat badan yang sama dengan anak laki-laki. Energi yang diperlukan 10 persen lebih rendah dari laki-laki. Kebutuhan gizi anak laki-laki lebih besar dari perempuan (Kartasapoetra dan Marsetyo, 2008).
Gershwin (2004) pada tahun pertama laki laki lebih berisiko malnutrisi karena ukuran tubuh lebih besar dan membutuhkan asupan lebih besar, jika tidak terpenuhi dalam jangka waktu lama akan meningkatkan risiko gangguan pertumbuhan. Pada tahun pertama kehidupan, laki-laki lebih rentan mengalami malnutrisi daripada perempuan karena ukuran tubuh laki-laki yang besar dimana membutuhkan asupan energi yang lebih besar pula sehingga bila asupan makan tidak terpenuhi dan kondisi tersebut terjadi dalam jangka waktu lama dapat meningkatkan gangguan pertumbuhan.

Menurut ramli et al bayi perempuan dapat bertahan hidup dalam jumlah besar dari pada bayi laki-laki di kebanyakan negara berkembang termasuk Indonesia. Penyebab ini tidak dijelaskan dalam literatur, tetapi ada kepercayaan bahwa tumbuh kembang anak laki-laki lebih dipengaruhi oleh tekanan lingkungan dibandingkan anak perempuan (Hien \& Kam, 2008).

Dalam hal ini lingkungan merupakan salah satu faktor yang mempengaruhi psikologis dalam tumbuh kembang anak (Hidayat, 2009).Hasil penilitianini serupadengan penelitian Aguayo dkk (2016) di India bahwa balita stunting lebih banyak berjenis kelamin laki-laki dari pada balita perempuan dan menyebutkan hasil analisis regresi multivariat menunjukan kemungkinan stunting pada anak laki-laki lebih tinggi $38 \%$ dari pada anak perempuan.Penelitian yang dilakukan adani \& Nindya (2017) juga didapatkan bahwa balita stunting lebih banyak terjadi pada laki-laki.

Berdasarkan tingkat pendidikan responden sebanyak 11 responden $(50,0 \%)$ lebih banyak berlatar belakang pendidikan sekolah menengah pertama (SMP). Notoatmodjo (2010) menyatakan pendidikan adalah kegiatan atau proses pembelajaran untuk mengembangkan atau meningkatkan 
kemampuan tertentu sehingga sasaran pendidikan itu dapat berdiri sendiri. Perubahan dan tindakan pemeliharaan dan peningkatan kesehatan yang dihasilkan oleh pendidikan kesehatan didasarkan kepada pengetahuan dan kesadarannya melalui proses pembelajaran.

Tingkat pendidikan yang rendah mempengaruhi terbatasnya akses terhadap praktek pengasuhan yang baik dan sarana kesehatan yang ada. Tingkat pendidikan ibu yang rendah dan pendapatan yang juga rendah umumnya menyebabkan kepercayaan diri ibu dalam mengakses sarana gizi dan kesehatan seperti Posyandu dan Puskesmas, termasuk aktivitas bina keluarga balita (BKB) rendah, sehingga amat perlu untuk dimotivasi.

Dalam penelitian Rahayu dkk (2014) pendidikan ibu memiliki hubungan yang bermakna dengan kejadian stuntinghal ini dikarenakan ibu dengan pendidikan $\geq$ SMP memiliki peluang lebih besar dalam mengakses informasi mengenai status gizi dan kesehatan anak sehingga penegtahuan nya meningkat, kemudian informasi tersebut dipraktikan dalam proses perawatan anak yang akan berimbas pada status gizi dan kesehatan anak yang lebih baik.

Hal ini sesuai dengan penelitian anisa (2012), bahwa kecenderungan kejadian stunting pada balita lebih banyak terjadi pada ibu berpendidikan rendah ibu yang berpendidikan baik akan membuat keputusan yang akan meningkatkan gizi dan kesehatan anak-anaknya dan cenderung memiliki pengetahuan gizi yang baik pula.

Hasil analisis menunjukan data pekerjaan sebanyak 28 responden $(63,4 \%)$ terdapat 12 responden pada kelompok kasus adalah ibu rumah tangga. Hal ini disesuaikan dengan penelitian yang dilakukan oleh anisa (2012) dan Neldawati (2006) bahwa ibu balita tidak bekerja memiliki status anak stunting lebih besar dan tidak ada hubungan yang bermakna antara pekerjaanibu dengan kejadian stunting.

Pekerjaan ibu berkaitan denngan pola asuh anak dan status ekonomi keluarga, ibu yang bekerja di luar rumah dapat menyebabkan anak tidak terawat sebab anak balita sangat tergantung pada pengasuhnya atau anggota keluarga yang lain, namun di lain pihak ibu yang bekerja dapat membantu pemasukan keluarga karena pekerjaan merupakan faktor penting dalam menentukan kualitas dan kuantitas pangan (diana, 2010).

Hal ini dengan penelitian Hermansyah (2018) yang menyatakan bahwa status stunting lebih banyak terdapat pada anak dengan ibu yang tidak bekerja. Meskipun ibu tidak bekerja memiliki banyak waktu untuk mengasuh anak tetapi jika pola asuh yang diberikan kurang baik seperti dalam pola makan kurang diperhatikan maka akan terjadi masalah gizi.

\section{B. Hasil Analisa Bivariat dan Pembahasan}

\section{Tabel 2}

Distribusi Frekuensi Responden Berdasarkan Pemberian ASI Eksklusif di Wilayah Kerja Puskesmas Kampung Dalam $(\mathrm{N}=44)$

\begin{tabular}{lcc}
\hline $\begin{array}{l}\text { Pemberian } \\
\text { ASI }\end{array}$ & $\mathrm{n}$ & $\%$ \\
\hline $\begin{array}{l}\text { Tidak ASI } \\
\text { eksklusif } \\
\text { ASI eksklusif }\end{array}$ & 23 & 52.3 \\
\hline \multicolumn{1}{c}{ Total } & 21 & 47.7 \\
\hline \multicolumn{2}{l}{ Sumber:data primer 2019} & 100.0 \\
\hline
\end{tabular}

Hasil penelitian pada pemberian ASI eksklusif sebanyak 23 responden (52,3\%) berada dalam kategori tidak mendapatkan ASI eksklusif. Pada kelompok kasus hampir semua penderita stunting tidak mendapatkan ASI eksklusif sedangkan kelompok kontrol 
yang bukan penderita stunting hanya $(18,2 \%)$ yang tidak mendapatkan ASI eksklusif.

Demikian pula pernyataan (Prasetyono, 2009) pemberian ASI eksklusif memberikan berbagai manfaat untuk ibu dan bayi dimana ASI merupakan makanan alamiah yang baik untuk bayi, praktis, ekonomis, mudah dicerna, memiliki komposisi zat gizi yang ideal sesuai dengan kebutuhan dan kemampuan pencernaan bayi dan ASI mendukung pertumbuhan bayi terutama tinggi badan karena kalsium ASI lebih efisien diserap dibanding susu pengganti ASI.

Tabel 3

Distribusi Frekuensi Responden Berdasarkan

Pemberian MP ASI tepat waktu di usia 6 bulan di

Wilayah Kerja Puskesmas Kampung Dalam

\begin{tabular}{llr}
\multicolumn{3}{c}{$(\mathrm{N}=44)$} \\
\hline $\begin{array}{l}\text { Pemberian MP ASI } \\
\text { tepat waktu }\end{array}$ & $\mathrm{n}$ & $\%$ \\
\hline Tidak tepat waku & 24 & 54.5 \\
Tepat waktu & 20 & 45.5 \\
\hline \multicolumn{1}{c}{ Total } & 44 & 100.0
\end{tabular}

Sumber:data primer 2019

Hasil penelitian menunjukan bahwa pemberian MP ASI tepat waktu oleh 44 responden pada kelompok kasus yaitu 17 responden $(77,3 \%)$ penderita stunting yang mendapatkan MP ASI tidak tepat waktu dan sebaliknya bukan penderita stunting sebanyak 17 responden $(68,2 \%)$ mendapatkan MP ASI tepat waktu. Menurut (WHO, 2010) pemberian MP ASI dini sebelum 6 bulan ataupun lebih dari 6 bulan dapat menyebabkan bayi kekurangan zat gizi dan akan mengalami kurang zat besi serta mengalami tumbuh kembang yang terlambat.

Sebagian besar penderita stunting di Puskesmas Kampung Dalam tidak mendapatkan MP ASI tepat waktu. Gangguan pertumbuhan pada bayi antara lain disebabkan oleh kekurangan gizi sejak bayi, pemberian MP ASI terlalu dini atau terlambat jadi MP
ASI yang diberikan tidak cukup gizinya sesuai kebutuhan bayi atau kurang baiknya pola pemberiannya menurut usia.

Temuan ini sejalan dengan penelitian yang dilakukan (khasanah, dwi dkk, 2016) yang membuktikan bahwa anak balita yang diberikan MP ASI sesuai dengan kebutuhannya dapat mengurangi resiko terjadinya stunting hal ini dikarenakan jika anak balita diberikan MP ASI dalam jumlah dan frekuensi yang cukup maka anak balita terpenuhi kebutuhan zat gizinya yang dapat mengurangi resiko terjadinya stunting.

Tabel 4

Hubungan Pemberian ASI eksklusif dengan kejadianstunting di Wilayah Kerja Puskesmas Kampung Dalam

\begin{tabular}{|c|c|c|c|c|c|}
\hline Pemberia & \multicolumn{2}{|c|}{ Kasus } & \multicolumn{2}{|c|}{$\begin{array}{r}\text { Kontrol } \\
\%\end{array}$} & p Value \\
\hline $\begin{array}{l}\text { n ASI } \\
\text { eksklusif }\end{array}$ & $\mathrm{n}$ & $\%$ & $\mathrm{n}$ & $\%$ & \\
\hline $\begin{array}{l}\text { TidakASI } \\
\text { eksklusif }\end{array}$ & $\begin{array}{l}1 \\
9\end{array}$ & 86.4 & 4 & 18.2 & \\
\hline $\begin{array}{l}\text { ASI } \\
\text { eksklusif }\end{array}$ & 3 & 13.6 & $\begin{array}{l}1 \\
8 \\
\end{array}$ & 81.8 & $\begin{array}{c}0,00 \\
0\end{array}$ \\
\hline Total & $\begin{array}{l}2 \\
2\end{array}$ & $\begin{array}{r}100 . \\
0\end{array}$ & $\begin{array}{l}2 \\
2\end{array}$ & $\begin{array}{r}100 . \\
0\end{array}$ & \\
\hline
\end{tabular}

Sumber:data primer 2019

Berdasarkan hasil analisis dengan menggunakan Chi Square di peroleh p value sebesar 0,000. Karena nilai sugnifikansi pada $0,000<0,05$ maka berdasarkan dasar pengambilan keputusan diatas dapat di simpulkan bahwa $\mathrm{H} 0$ ditolak dan Ha diterima. Dengan demikian dapat diartikan bahwa "Ada hubungan yang signifikan antara pemberian ASI eksklusif dengan kejadian stunting di wilayah kerja Puskesmas Kampung Dalam”.

Pemberian ASI eksklusif pada balita dalam penelitian ini didapatkan bahwa sebagian besar balita tidak mendapatkan ASI eksklusif. Hal ini dapat dimaknai bahwa pemberian ASI eksklusif pada balita mempengaruhi terhadap angka kejadian stunting. Karena pemberian ASI secara 
eksklusif itu penting kandungan ASI sendiri sesuai dengan kebutuhan bayi,ASI juga mendukung pertumbuhan bayi karena kalsium yang ada dalam ASI mudah untuk diserap.

Menurut Maryunani (2010) pertumbuhan dan perkembangan pada bayi memerlukan masukan zat-zat gizi yang seimbang dan relatif besar. Namun kemampuan bayi untuk makan dibatasi oleh keadaan saluran pencernaan yang masih dalam tahap pendewasaan. Satu-satunya makanan yang sesuai dengan keadaan saluran pencernaan bayi dan memenuhi kebutuhan selama berbulan-bulan pertama adalah ASI.

Hasil penelitian ini berkaitan dengan manfaat pemberian ASI, bayi yang mendapatkan ASI mempunyai kenaikan berat badan yang lebih baik setelah lahir dan pertumbuhan setelah periode parinatal baik. ASI juga mengandung komposisi yang tepat terdiri dari proporsi yang seimbang dan cukup kuantitas semua zat gizi yang diperlukan untuk kehidupan 6 bulan pertama.

Anak yang tidak mendapatkan ASI eksklusif beresiko lebih tinggi untuk kekurangan zat gizi yang diperlukan untuk proses pertumbuhan. Gangguan pertumbuhan akan mengakibatkan terjadinya stunting pada anak (Anshori,2013). Hal ini sejalan dengan penelitian yang dilakukan Agustina (2015) yang membuktikan terdapat hubungan antara ASI eksklusif dengan stunting di Puskesmas Lima Puluh Pekan Baru.

Hasil temuan dilapangan bahwa dengan didapatkan pemberian ASI eksklusif yang belum optimal dapat menjadi acuan dalam upaya meningkatkan upaya preventif maupun kuratif dalam pemberian ASI eksklusif sehingga tercapai harapan yang dinginkan pemerintah dalam program yang dibuat untuk mengatasi masalah stunting yang menjadi salah satu prioritas pembangunan nasional yang tercantum didialam sasaran pokok Rencana Pembangunan Jangka Menengah (RPJM) tahun 2015-2019.

Hasil analisis OR mempunyai nilai 28,500 yang mempunyai arti responden yang tidak mendapatkan ASI eksklusif memiliki resiko 28,500 kalilebih besar mengalami stunting. OR lebih dari 1 maka pemberian ASI eksklusif dan terjadinya stunting (berkorelasi) dalam arti bahwa kurangnya responden dalam mendapatkan ASI eksklusif dapat meningkatkan peluang terjadinya stunting.

\section{Tabel 5}

Hubungan Pemberian MP ASI Tepat Waktu dengan kejadian stunting di Wilayah Kerja Puskesmas Kampung Dalam

$$
(\mathrm{N}=44)
$$

\begin{tabular}{|c|c|c|c|c|c|}
\hline \multirow{2}{*}{$\begin{array}{l}\text { MP ASI } \\
\text { tepat waktu }\end{array}$} & \multicolumn{2}{|c|}{ Kasus } & \multicolumn{2}{|c|}{ Kontrol } & \multirow[t]{2}{*}{ p Value } \\
\hline & $\mathrm{n}$ & $\%$ & $n$ & $\%$ & \\
\hline Belum/lebi & 1 & 77.3 & 7 & 31.8 & \\
\hline $\begin{array}{l}\text { h dari } 6 \\
\text { bulan }\end{array}$ & 7 & & & & \\
\hline $\begin{array}{l}\text { Tepat } 6 \\
\text { bulan }\end{array}$ & 5 & 22.7 & $\begin{array}{l}1 \\
5\end{array}$ & 68.2 & $\begin{array}{c}0,00 \\
2\end{array}$ \\
\hline Total & $\begin{array}{l}2 \\
2\end{array}$ & $\begin{array}{r}100 . \\
0\end{array}$ & $\begin{array}{l}2 \\
2\end{array}$ & $\begin{array}{r}100 . \\
0\end{array}$ & \\
\hline
\end{tabular}

Berdasarkan hasil analisis dengan menggunakan Uji Chi Square diperoleh nilai p value 0,002 . Karena nilai signifikansi 0,000 $<0,05$ maka berdasarkan pengambilan keputusan diatas, dapat disimpulkan bahwa HO ditolak dan Ha diterima. Dengan demikian dapat diartikan bahwa " Ada hubungan yang signifikan antara pemberian MP ASI tepat waktu dengan kejadian stunting di wilayah kerja Puskesmas Kampung Dalam”.

Hal ini menujukan pemberian MP ASI pada balita belum tepat waktu. Makanan Pendamping ASI sendiri merupakan makanan yang diberikan kepada anak bersamaan dengan ASI, MP ASI bersifat untuk melengkapi ASI bukan untuk menggantikan ASI dan ASI harus tetap diberikan sampai 
usia 2 tahun diikuti dengan pemberian MP ASI pada usia 6 bulan.

Pada saat berat badan bayi bertambah dan bayi berkembang menjadi lebih aktif dan umumnya mencapai tahapan dimana ASI saja sudah tidak cukup untuk memenuhi kebutuhan gizi bayi. Karena itu MP ASI diperlukan untuk menutupi kekurangan antara total kebutuhan bayi dan jumlah yang dapat dipenuhi ASI. (Posdatin, 2018).

Tujuan pemberian MP ASI sendiri adalah untuk menambah energi dan zat-zat gizi yang diperlukan bayi karena ASI tidak dapat memenuhi kebutuhan bayi secara terus menerus (Yesrina, 2008).Dengan demikian makanan tambahan diberikan untuk mengisi kesenjangan antara kebutuhan nutrisi total pada anak dengan jumlah yang didapatkan dari ASI. Adapun waktu pemberian MP ASI sebelum 6 bulan ataupun lebih dari 6 bulan dapat menyebabkan bayi kekurangan zat gizi dan akan mengalami kurang zat besi serta mengalami tumbuh kembang yang terlambat.

Dalam penelitian Farah dkk, (2015) yang dilakukan di Jember tentang faktor-faktor yang mempengaruhi kejadian stunting pada anak balita di wilayah perdesaan dan perkotaan, bahwa hasil analisis hubungan umur pertama pemberian MP ASI dengan stunting pada anak balita merupakan salah satu faktor yang mempengaruhi terjadinya stunting.

Hal ini sejalan dengan penelitian Khasanah dkk, (2016) bahwa terdapat hubungan waktu pemberian MP ASI dengan kejadian stunting. Hal ini yang menyebabkan kejadian stunting oleh karena itu diperlukan sikap petugas kesahatan dalam hal penyuluhan kesehatan dengan cara menyebarkan pesan, memberi pemahaman, sehingga masyarakat paham penting nya pemberian MP ASI tepat waktu.
Hasil analisis OR mempunyai nilai 7,286 yang mempunyai arti responden yang tidak mendapatkan MP ASI tepat waktu memiliki resiko 7,286 kali lebih besar mengalami stunting. OR lebih dari 1 maka pemberian MP ASI tepat waktu dan terjadinya stunting (berkorelasi) dalam arti bahwa kurangnya responden dalam mendapatkan MP ASI tepat waktu dapat meningkatkan peluang terjadinya stunting.

\section{KESIMPULAN}

Berdasarkan hasil penelitian dapat dirumuskan beberapa simpulan sebagai berikut :

1. Jenis kelamin responden yang lebih banyak pada kelompok kasus yaitu laki-laki sebanyak 12 responden $(54,5 \%)$, rata rata responden berpendidikan terakhir SMP sebanyak 17 responden $(38,6 \%)$ dan mayoritas pekerjaan responden adalah ibu rumah tangga sebanyak 28 responden $(63,4 \%)$.

2. Sebanyak 23 responden $(52,3 \%)$ tidak mendapatkan Asi eksklusif.

3. Sebanyak 24 responden $(54,5 \%)$ di berikan MP ASI tidak tepat waktu

4. Hasil analisis hubungan ASI dengan kejadian stunting didapatkan nilai $\mathrm{p}$ value 0,000 dan hubungan MP ASI dengan kejadian stunting nilai $\mathrm{p}$ value 0,002 sehingga dapat ditarik kesimpulan ada hubungan yang signifikan antara pemberian ASI dan MP ASI dengan kejadian stunting pada baduta di wilayah kerja Puskesmas Kampung Dalam 


\section{DAFTAR PUSTAKA}

Adani, F.Y., \& Nindya, T.S. (2017). Perbedaan asupan enrgi, protein, zink dan perkembangan pada balita stuntimh dan non stunting. Amerta nutrion.

Anisa, Paramitha. (2012). Faktorfaktor yang berhubungan dengan kejadian stunting pada balita usia 25-60 bulan dikelurahan kalibaru. Skripsi FKM UI Jakarta.

Dewey, K.G., Begum, K.2011. Long Term Consequences of Stunting In Early Life. Maternal Child Nurt. Vol 3. Hal: 5-18.

Diana, M. (2010). Buku pintar ASI eksklusif. Yogyakarta : Diva press

Dinkes Kesehatan. (2018). Laporan Hasil Survei Pemantauan Status Gizi Ballita Kota Pontianak.

Dwitama, dkk. (2018). Hubungan Pemberian Asi Ekslusif dan Makanan Pendamping ASI Terhadap Balita Pendek Usia 2-5 Tahun di Kecamatan Jatinagor.

Gershwin M, Nestel P, Keen C,. (2004). Handbook of nutrision and immunity. New jersey : Humma press.

Hidayat, A.A (2009). Pengantar ilmu kesehatan anak untuk pendidikan kebidanan. Jakarta : salemba medika.

Hien, NN dan Kam, S. (2008). Nutritional status and the characteristich related to malnutrition in childern under five years og age in nghean. Vietna: J prev med publich health 41 (4) : 232-240.

Infodatin. (2016). Situasi Balita Pendek. Diakses pada tanggal 20 april 2019

Kartasapoetra, G. Drs, dan Marsetyo, Drs, Med. (2008). Ilmu gizi, korelasi gizi, kesehatan dan prodiktifitas kerja. Jakarta : Rineka cipta.
Maryani, Aruk. (2010). Iilmu kesahatan anak dalam kebidanan. Jakarta : CV trans info media.

Neldawati. (2006). Hubungan pola pemberian makan pada anak dan karakteristik lain dengan status gizi di laboratorium gizi masyarakat puslitbang gizi dan makanan. Depok : FKM UI.

Notoatmdjo, S. (2010). Ilmu kesehatan masyararakat. Jakarta : Rineka cipta.

Nurkomala, S. (2017). Praktik Pemberian MPASI Pada Anak Stunting dan Tidak Stunting 6-24 bulan Universitas Ponegoro Semarang.

Posdatin. (2018) situasi balita pendek (stunting) diIdonesia. Diakses tanggal $20 \quad$ April 2019.

Turyashemereswa, F.M., Kikafunda, J.K., Agaba, E. (2009). Prevalence of Early Childhood Malnutrition and Influencing Factors In Periurban Areas of Kabarole Dsitrict. Western Uganda. Afrika Journal of Food Agriculture Nutrition and Development. Vol 4. Hal: 975989.

Warta Kesmas. (2018). Cegah Stunting Itu Penting. Edisi (02) diakses tanggal $23 \quad$ april 2019.

World Health Oraginzation. (2010). Nutrion Landsape Information System: ountry Profiles Indicates.

World Health Oraginzation. (2012). Development og a strategy towards promoting optimal fetal growth. Diakses tanggal 27 juni 2019. 